University of Nebraska - Lincoln

DigitalCommons@University of Nebraska - Lincoln

Papers in the Earth and Atmospheric Sciences

Earth and Atmospheric Sciences, Department

$9-1982$

\title{
Early History of the Atlantic Ocean and Gas Hydrates on the Blake Outer Ridge: Results of the Deep Sea Drilling Project Leg 76
}

\author{
Robert E. Sheridan \\ University of Delaware \\ Felix M. Gradstein \\ Atlantic Geoscience Centre \\ Leo A. Barnard \\ Texas A\&M University \\ Deborah M. Bliefnick \\ University of California - Santa Cruz \\ Dan Habib \\ Queens College \\ See next page for additional authors \\ Follow this and additional works at: https://digitalcommons.unl.edu/geosciencefacpub \\ Part of the Earth Sciences Commons
}

\begin{abstract}
Sheridan, Robert E.; Gradstein, Felix M.; Barnard, Leo A.; Bliefnick, Deborah M.; Habib, Dan; Jenden, Peter D.; Kagami, Hideo; Keenan, Everly M.; Kostecki, John; Kvenvolden, Keith A.; Moullade, Michel; Ogg, James; Robertson, Alastair H.F.; Roth, Peter H.; Shipley, Thomas H.; Wells, Larry; Bowdler, Jay L.; Cotillon, Pierre H.; Halley, Robert B.; Kinoshita, Hajimu; Patton, James W.; Pisciotto, Kenneth A.; Premoli-Silva, Isabella; Testarmata, Margaret M.; Tyson, Richard V.; and Watkins, David K., "Early History of the Atlantic Ocean and Gas Hydrates on the Blake Outer Ridge: Results of the Deep Sea Drilling Project Leg 76" (1982). Papers in the Earth and Atmospheric Sciences. 257.

https://digitalcommons.unl.edu/geosciencefacpub/257
\end{abstract}

This Article is brought to you for free and open access by the Earth and Atmospheric Sciences, Department of at DigitalCommons@University of Nebraska - Lincoln. It has been accepted for inclusion in Papers in the Earth and Atmospheric Sciences by an authorized administrator of DigitalCommons@University of Nebraska - Lincoln. 


\section{Authors}

Robert E. Sheridan, Felix M. Gradstein, Leo A. Barnard, Deborah M. Bliefnick, Dan Habib, Peter D. Jenden, Hideo Kagami, Everly M. Keenan, John Kostecki, Keith A. Kvenvolden, Michel Moullade, James Ogg, Alastair H.F. Robertson, Peter H. Roth, Thomas H. Shipley, Larry Wells, Jay L. Bowdler, Pierre H. Cotillon, Robert B. Halley, Hajimu Kinoshita, James W. Patton, Kenneth A. Pisciotto, Isabella Premoli-Silva, Margaret M. Testarmata, Richard V. Tyson, and David K. Watkins 


\section{Early history of the Atlantic Ocean and gas hydrates on the Blake Outer Ridge: Results of the Deep Sea Drilling Project Leg 76}

ROBERT E. SHERIDAN Department of Geology, University of Delaware, Newark, Delaware 197II

FELIX M. GRADSTEIN Atlantic Geoscience Centre, Bedford Institute of Oceanography, Dartmouth, Nova Scotia, B3Y 4A2, Canada

LEO A. BARNARD Department of Oceanography, Texas A\&M University, College Station, Texas 77843

DEBORAH M. BLIEFNICK Earth Sciences Department, University of California, Santa Cruz, Santa Cruz, California 95064

DAN HABIB Department of Earth and Environmental Sciences, Queens College, Flushing, New York 11367

PETER D. JENDEN Institute of Geophysics and Planetary Physics, University of California, Los Angeles, 405 Hilgard Avenue, Los Angeles, California 90024

HIDEO KAGAMI Ocean Research Institute, University of Tokyo, Nakano, Tokyo 164, Japan

EVERLY M. KEENAN Department of Geology, University of Delaware, Newark, Delaware 19711

JOHN KOSTECKI Lamont-Doherty Geological Observatory, Columbia University, Palisades, New York 10964

KEITH A. KVENVOLDEN Pacific-Arctic Branch of Marine Geology, U.S. Geological Survey, 345 Middlefield Road,

Menlo Park, California 94025

MICHEL MOULLADE Centre de Recherches Micropaleontologiques, Universite de Nice, Parc Valrose, 06034 Nice Cedex, France JAMES OGG Geological Research Division, A-008, Scripps Institution of Oceanography, La Jolla, California 92093

ALASTAIR H.F. ROBERTSON Department of Geology, University of Edinburgh, West Mains Road, Edinburgh EH9 $3 J W$, United Kingdom

PETER H. ROTH Department of Geology and Geophysics, University of Utah, Salt Lake City, Utah 84112

THOMAS H. SHIPLEY Scripps Institution of Oceanography, La Jolla, California 92093

LARRY WELLS Scientific Software Corporation, First of Denver Plaza, 18th Floor, 633 Seventeenth Street,

Denver, Colorado 80202

JAY L. BOWDLER Union Oil Company of California, 900 Executive Plaza West, 4635 Southwest Freeway, Houston, Texas 77084

PIERRE H. COTILLON Departement de Geologie, Universite Claude Bernard, 29-43 Bd du 11 Novembre, 69622 Villeurbanne Cedex, France

ROBERT B. HALLEY Branch of Oil and Gas Resources, U.S. Geological Survey, Box 25046, M.S. 934, Denver Federal Center, Denver, Colorado 80225

HAJIMU KINOSHITA Department of Geophysics, Faculty of Science, Chiba University, 133, Yayoi-cho, Chiba 260, Japan

JAMES W. PATTON Marathon Oil Company, P.O. Box 269, Littleton, Colorado 80160

KENNETH A. PISCIOTTO Deep Sea Drilling Project, A-03I, Scripps Institution of Oceanography, La Jolla, California 92093

ISABELlA PREMOLI-SILVA Instituto di Paleontologia, Universita di Milano, Piazzale Gorini 15, Milano 20133, Italy

MARGARET M. TESTARMATA Marine Science Institute, University of Texas, 700 The Strand, Galveston, Texas 77550

RICHARD V. TYSON Department of Earth Sciences, The Open University Milton Keynes, Bucks, England

DAVID K. WATKINS Department of Geology, Florida State University, Tallahassee, Florida 32306

\section{ABSTRACT}

Leg 76 of the Deep Sea Drilling Project achieved two major scientific objectives. The first objective was met at Site 533, where on the Blake Outer Ridge, gas hydrates were identified by geophysical, geochemical, and geological studies. Gashydrate decomposition produced a volumetric expansion of 20:1 of gas volume to pore-fluid volume; this expansion exceeded by about a factor of four the volume of gas that could be released from solution in pore water under similar conditions. The gas hydrate includes methane, ethane, propane, and isobutane but apparently excluded normal butane and higher molecular weight hydrocarbons as predicted from gas hydrate crystallography. For the first time, marine gas hydrates were tested with a pressure core barrel.

The second objective was achieved when coring at Site 534 in the Blake-Bahama Basin sampled the oldest oceanic sediments yet recovered. The sequence of oceanic basement and overlying sediments documents the geologic history of the early stages of the opening of the North Atlantic Ocean in detail. The oldest oceanic sediments are red claystones and laminated green and brown claystones of middle Callovian age. This finding supports the interpretation that the beginning of the modern North Atlantic occurred in the early Callovian ( 155 m.y. B.P.), as much as 20 m.y. later in time than often previously thought.

Geological Society of America Bulletin, v. 93, p. 876-885, 8 figs., 1 table, September 1982. 
RESULTS OF DSDP LEG 76

TABLE 1. LEG 76 CORING SUMMARY

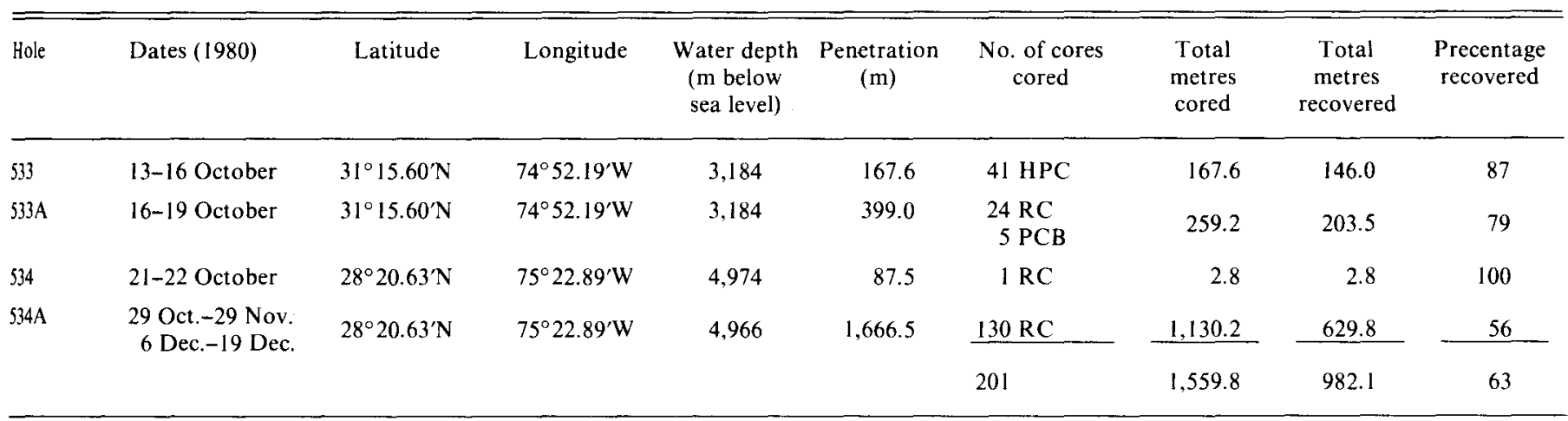

$\mathrm{HPC}=$ hydraulic piston core; $\mathrm{RC}=$ rotary core; $\mathrm{PCB}=$ pressure core barrel. Water depth corrected metres from echo sounding.

\section{INTRODUCTION}

Leg 76 of the Deep Sea Drilling Project (DSDP) began on 11 October 1980, in Norfolk, Virginia, and ended on 21 December 1980 in Fort Lauderdale, Florida (Table 1). The cruise, which operated in the same area (Fig. 1) as DSDP Legs 11 and 44, concentrated on scientific and potentially economic objectives not accomplished previously. The two principal goals of drilling on this part of the eastern North American margin were:

1. To document geologically, geochemically, and geophysically gas hydrates in the upper Tertiary sediments above the bottom simulating seismic reflector in the Blake Outer Ridge (Site 533), and to sample these gas hydrates with the pressure core barrel.

2. For the first time to continuously core Upper and Middle Jurassic strata below reflector $\mathrm{D}$, and reach oceanic basement in the M-28 marine magnetic anomaly zone in the Blake Bahama Basin (Site 534).

Both of these objectives were successfully achieved. We will discuss the preliminary results based on shipboard observations augmented by the preliminary information from shore-based studies.

\section{SITE 533: GAS HYDRATES ON THE BLAKE OUTER RIDGE}

The Blake Outer Ridge is an unusual topographic feature, extending southeast as a spit-like extension of the continental rise, which shoals to $1,500 \mathrm{~m}$ above the abyssal plain (Fig. 1). Extensive studies have shown that the Ridge formed in late Cenozoic time through accretion of hemipelagic mud by contour-following currents (Heezen and

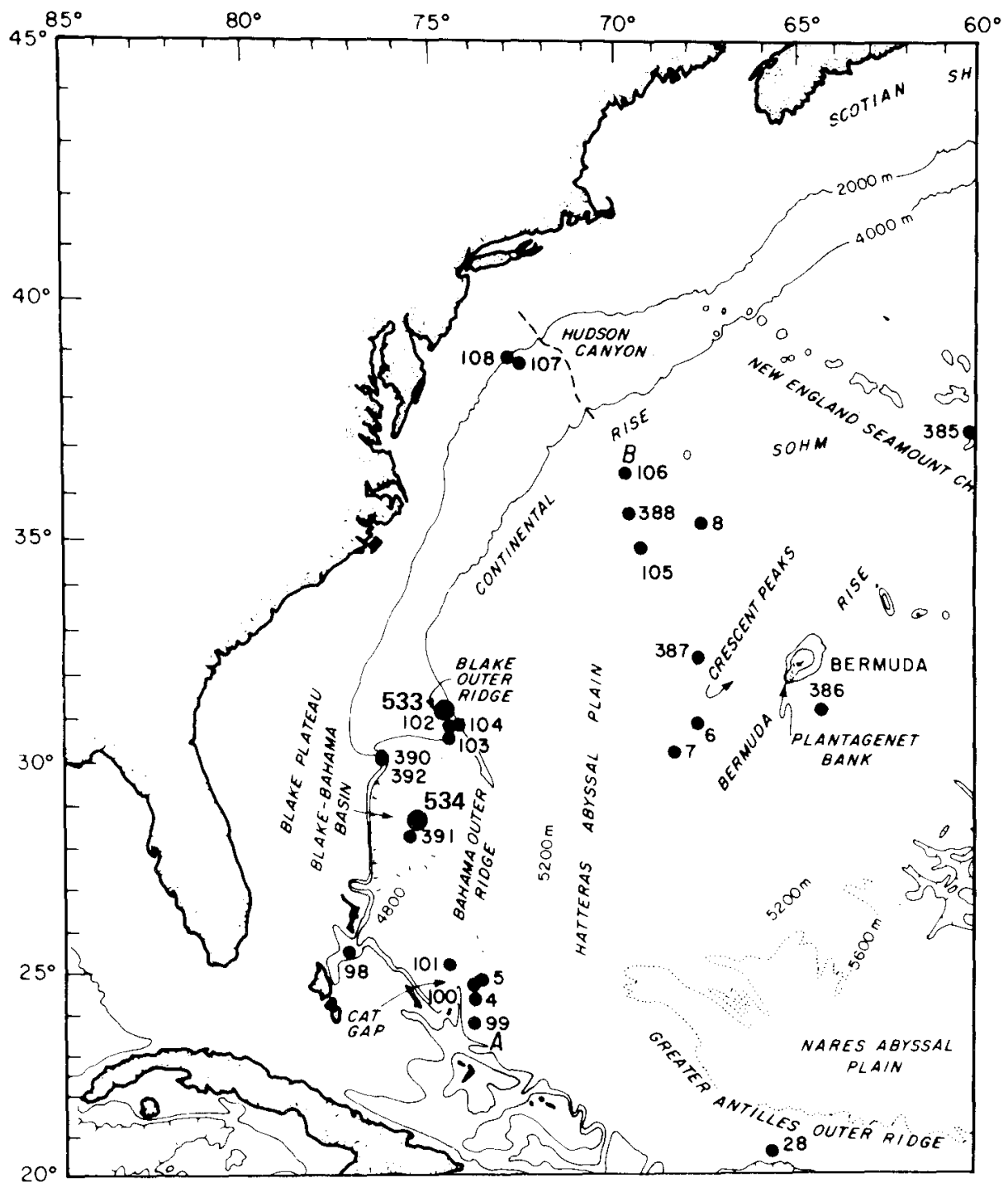

Figure 1. Location of DSDP Leg 76, Site 533 on the Blake Outer Ridge and of Site 534 in the Blake-Bahama Basin. 
others, 1966). DSDP Leg 11 established sedimentation rates as high as 5 to 15 $\mathrm{cm} / 10^{3} \mathrm{yr}$ and encountered very gassy sediments (Hollister, Ewing, and others, 1972). A fundamental phenomenon documented during Leg 11 was the time-transgressive nature of an acoustic reflector that approximately parallels the sea floor. This reflector is commonly called a Bottom Simulating Reflector (BSR) (Fig 2). One explanation for the BSR is that it represents the base of a zone where gas hydrates are stable. Gas hydrate would be stable under the temperature and pressure regime in the uppermost few hundred metres of Ridge sediment but would change to a fluid gas phase at a pressure-temperature-controlled phase boundary represented by the BSR. AIthough the acoustic evidence for a BSR is supported by theoretical considerations of the gas hydrate stability field and by preliminary geochemical observations made during Leg 11, confirmation of the presence of gas hydrates required in situ testing and further geochemical analysis. This work was accomplished at Site 533 on the Blake Outer Ridge.

\section{Operations}

The site was occupied from 13 to 19 October 1980. We drilled two holes at the same location (533 and 533a) in 3,184 m of water and took 41 hydraulic piston cores $(0-167.5 \mathrm{~m}), 24$ rotary cores, five pressure core barrel (PCB) cores (141.5-399.0 m) and three heat probe measurements to total

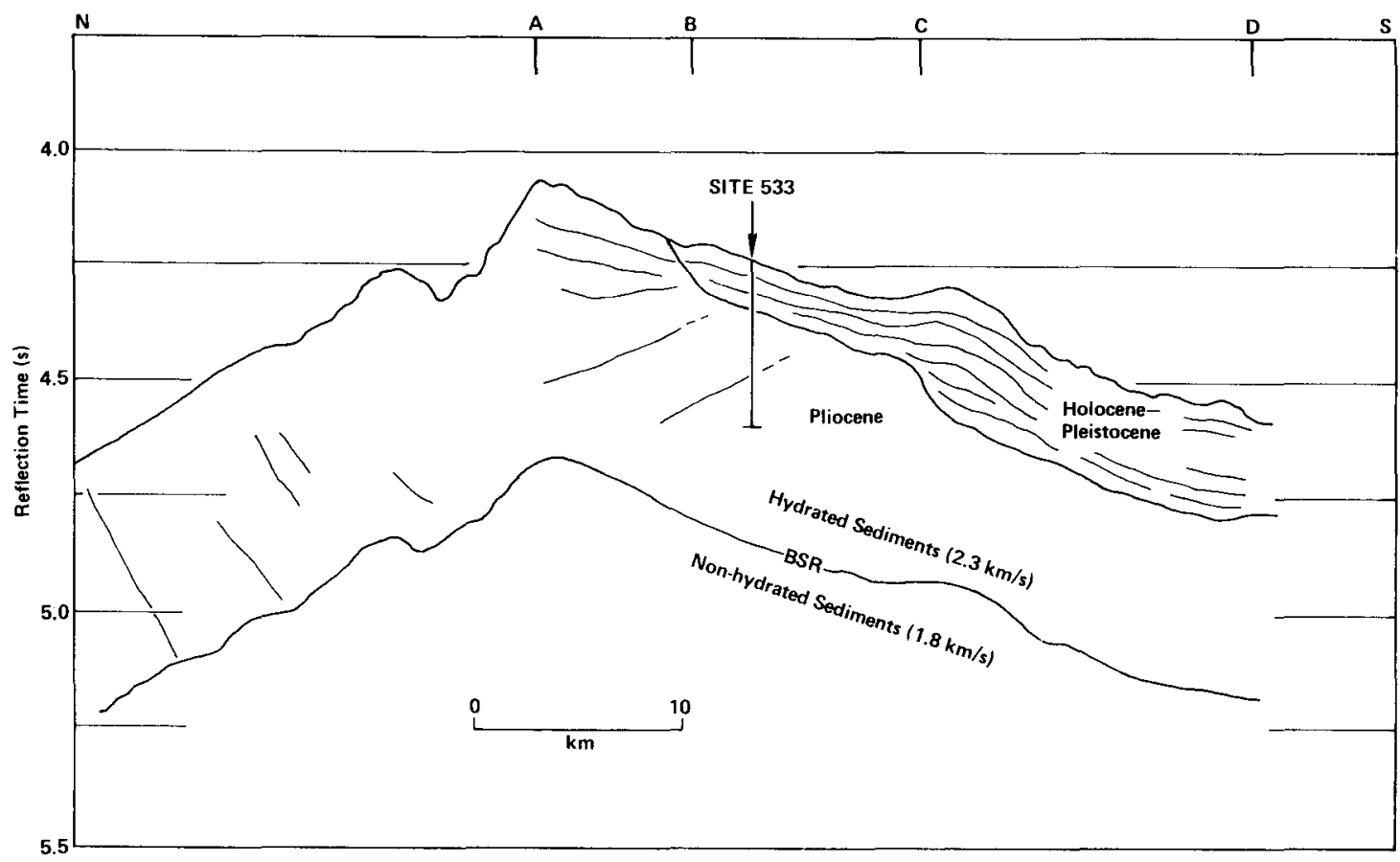

depth (Table 1). Although five PCB runs recovered cores, only four were pressurized. Three were at $\sim 4,500 \mathrm{psi}$ and one at 1,500 psi. Total sediment recovery was $82 \%$. Seismic-reflection profiles clearly show the BSR at the site as well as a marked angular unconformity between the BSR and the sea floor. Two near-site sonobuoy experiments complement the detailed geological, geochemical, and geophysical studies made in Holes 533 and 533a. Logging of Site 533 was prevented by failure of the bit release mechanism.

\section{Stratigraphy and Depositional History}

Preliminary biostratigraphic analysis of the cores from Site 533 allowed recognition of at least ten Pliocene-Pleistocene nannofossil zones and an equal number of foraminiferal datums. We found two well-identified lithologic units in Site 533. The oldest one, Unit 2, is a dark, greenish-gray, calcareous clay and mud of possibly middle to late Pliocene age which shows a general lack of bedding. The age data indicate a high middle Pliocene sedimentation rate of 21 $\mathrm{cm} / 10^{3} \mathrm{yr}$, decreasing to $8 \mathrm{~cm} / 10^{3} \mathrm{yr}$ in late Pliocene time. A very low sedimentation rate of $1 \mathrm{~cm} / 10^{3} \mathrm{yr}$ during latest Pliocene to earliest Pleistocene time implies sediment bypassing or erosion. This suggestion would agree with the seismic interpretation of an angular unconformity between Units 1 and 2 at $158 \mathrm{~m}$ sub-bottom (Fig. 2). The hiatus, dating back to $1.8-2.1 \mathrm{~m} . \mathrm{y}$, is probably related to one of the pulses of Northern Hem- isphere glaciation which apparently enhanced deep circulation and deep basin erosion.

Unit 1 is a light gray-green and rosecolored nannofossil-rich clay and mud of Pleistocene through Holocene age. Deposited at relatively high sedimentation rates of $7 \mathrm{~cm} / 10^{3} \mathrm{yr}$, this unit shows striking variations in microfossil assemblages, calciumcarbonate content, and color that are associated with the climatic variations during the Pleistocene. Unexpectedly low levels of reworked nannofossils suggest predominantly Quaternary sources of the clastics that are similar to clastic sediments found along the continental slopes to the north The continuous coring and geographically oriented piston cores recovered at the site makes Site 533 valuable for detailed investigations of the Quaternary deep ocean.

The Blake Outer Ridge is commonly thought to have formed by sediment transported by geostrophic contour currents (Heezen and others, 1966). While there is substantive evidence based on geomorphologic and seismic data for this conclusion (Markl and others, 1970), we observed almost no current-formed structures in the cores at Site 533. The Quaternary unit is seemingly almost structureless except for some layers of very fine silt with no visible lamination. These thin beds, however, do not appear to be common but rather are the exception at Site 533, whereas contourites

Figure 2. North-tosouth seismic profile over the Blake-Bahama Outer Ridge at DSDP Site 533 in $3,190 \mathrm{~m}$ of water. The Bottom Simulating Reflector (BSR) is thought to represent the phase change from hydrated to non-hy. drated sediments below. Geochemical and thermal observations during drilling confirm the presence of some hydrates and explain the position of the BSR. The Ridge was built from contourfollowing currents, but the cored sediments showed little visual evidence of the ubiquitously laminated sediments which signal classical contourites. 
are supposed to be "ubiquitously laminated" (Bouma and Hollister, 1973). The Pliocene unit exhibits apparent fissile structure throughout, either resulting from compaction or preferred orientation of components due to current action. Because of the lack of visible structures in the sediments, we lack direct evidence of classical contourite deposition at Site 533 (Heezen and others, 1966). However, the lack of structure and texture does not preclude such a mechanism of deposition, especially if deposition is through a gentle current from a nepheloid layer.

\section{Geochemical Measurements}

The organic geochemical sampling at Site 533 consisted of analysis of (1) gas collected directly from the core by means of evacuated containers called "vacutainers," (2) gas extracted from segments of sediments by equilibration into a helium headspace, (3) quantatitive pressure and volume measurements on samples of solid gas hydrates, and (4) pressure measurements and gas recovery utilizing the pressure core barrel (PCB). Methane was present in high concentrations, and the large methane/ethane ratios (ranging down the hole from about 35,000 to 4,000 ) indicate that the methane is of biologic origin (Bernard and others, 1978). Preliminary measurements of the carbon isotopic composition of the methane, ranging from $-67 \%$ to $-91 \%$ relative to the Pee Dee belemnite standard, support the contention of a biologic origin for the methane (Claypool and others, 1973). The downward decreasing values of methane/ethane ratios have been commonly found in DSDP samples (Whelan and Sato, 1980), and this decrease is probably caused by processes of early thermal diagenesis.

The most significant result of the quantitative organic geochemical measurements was the documentation of gas hydrates. We measured a 20:1 volumetric expansion (gas volume to pore-fluid volume) of a gas hydrate sample in Core 13 at $\sim 240 \mathrm{~m}$ subbottom depth. The volume of methane observed was greater than could be in solution with normal pore water. More important, the composition of the hydrocarbon gases released upon gas hydrate decomposition excluded the higher hydrocarbons (normal butane and larger hydrocarbons), which do not fit in the hydrate cage structure (Hand and others, 1974). This observation is the first experimental evidence that gas hydrates in the marine environment follow this predicated behavior.

Three of five PCB deployments maintained sediments under high pressure of $\sim 4,500$ psi, and permitted experimental measurements of gas pressure as a function of temperature and time (Fig. 3). On two of the PCB cores, the pressure-time curves followed the saw-tooth pattern expected for gas hydrates decomposing under increases in temperature and stepwise decreases in pressure. These observations are the first such experimental evidence for gas hydrates in the marine environment.

Still uncertain are the quantities of gas hydrates present at Site 533. Our direct observations of the hydrates in the opened cores amounted to a few thin mat-like crystals and frothy layers in Core 13; it is not known what amounts of hydrates (perhaps finely distributed) in the 6-m-long pressurized section of the PCB were producing the pressure effects observed. Gas hydrates may be present only in centimetre- or millimetrethin layers or dispersed in the small pores of the fine-grained sediment.

Low interstitial water salinities and chlorinities were associated with the gas/hydrate interval-for example, relatively low values of $31.6 \%$ salinity and $17.2 \%$ chlorinity were observed at 294-m sub-bottom depth. Similar depletions in salinity and chlorinity were also observed on the Blake Outer Ridge at Site 102 on Leg 11 (Sayles and others, 1972), and large salinity and chlorinity depletions are associated with gas hydrates at Sites 496 and 497 of Leg 67 off western Guatemala (Hesse and Harrison, 1980). It has long been known that gas hydrates exclude salt during crystallization (Hand and others, 1974). Hesse and Harrison (1980) proposed that this "excess" salt leaves hydrate-bearing sediments, presumably by advection and diffusion. Rapid decomposition of hydrates during core recovery would then cause shipboard depletions in interstitial water salinity. The observed chlorinity and salinity depletions at Site 533 support the suggestions above that only a portion of the sediment pore space is filled with gas hydrates.

\section{Acoustic Properties and Seismic Stratigraphy}

Measurements with two well-positioned sonobuoys made by D/V Glomar Challenger at Site 533 yielded on the average higher compressional wave velocities than for normal deep-sea sediments above the bottom simulating reflector. These relatively high velocities contrast with the more nor-
Figure 3. Evidence for gas hydrates in pressure core barrel no. 5 at $390 \mathrm{~m}$ in Site 533, Blake-Bahama Outer Ridge. The distinctive saw-tooth pattern of pressure change recorded is typical of gas hydrate decomposing under increasing temperature and step-wise decreasing pressure (that is, the pressure is vented several times and after each venting allowed to build up again).

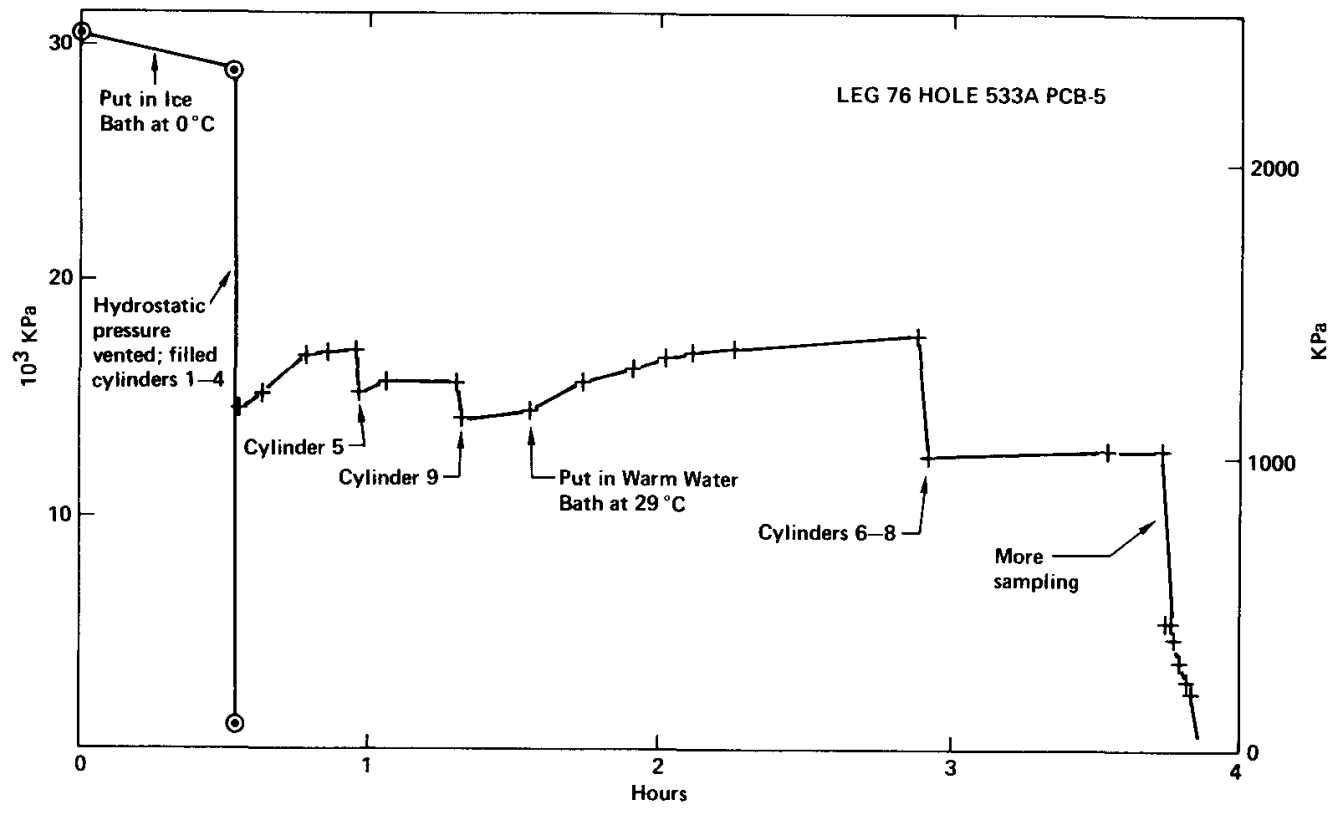


mal sediment velocities measured on the average for the interval below the BSR (Fig. 2). Such occurrences of relatively higher seismic velocity above the BSR have been observed elsewhere on the Blake Outer Ridge (Hollister, Ewing, and others, 1972; Paull and Dillon, 1979; Dillon and others, 1980), and it possibly represents a real situa- tion over most of the area. The higher velocities above the BSR can be attributed to the presence of thin layers of gas hydrates interlayered with normal sediments, or to small particles of gas hydrate at the grain contacts, producing a cementation effect. The spatial distribution and actual situation of the gas hydrate in the pore space is still enigmatic, as is the actual amount of gas hydrate needed to cause these higher seismic velocities.

\section{Temperature}

Temperatures are documented at Site 533 by well-equilibrated temperature probe

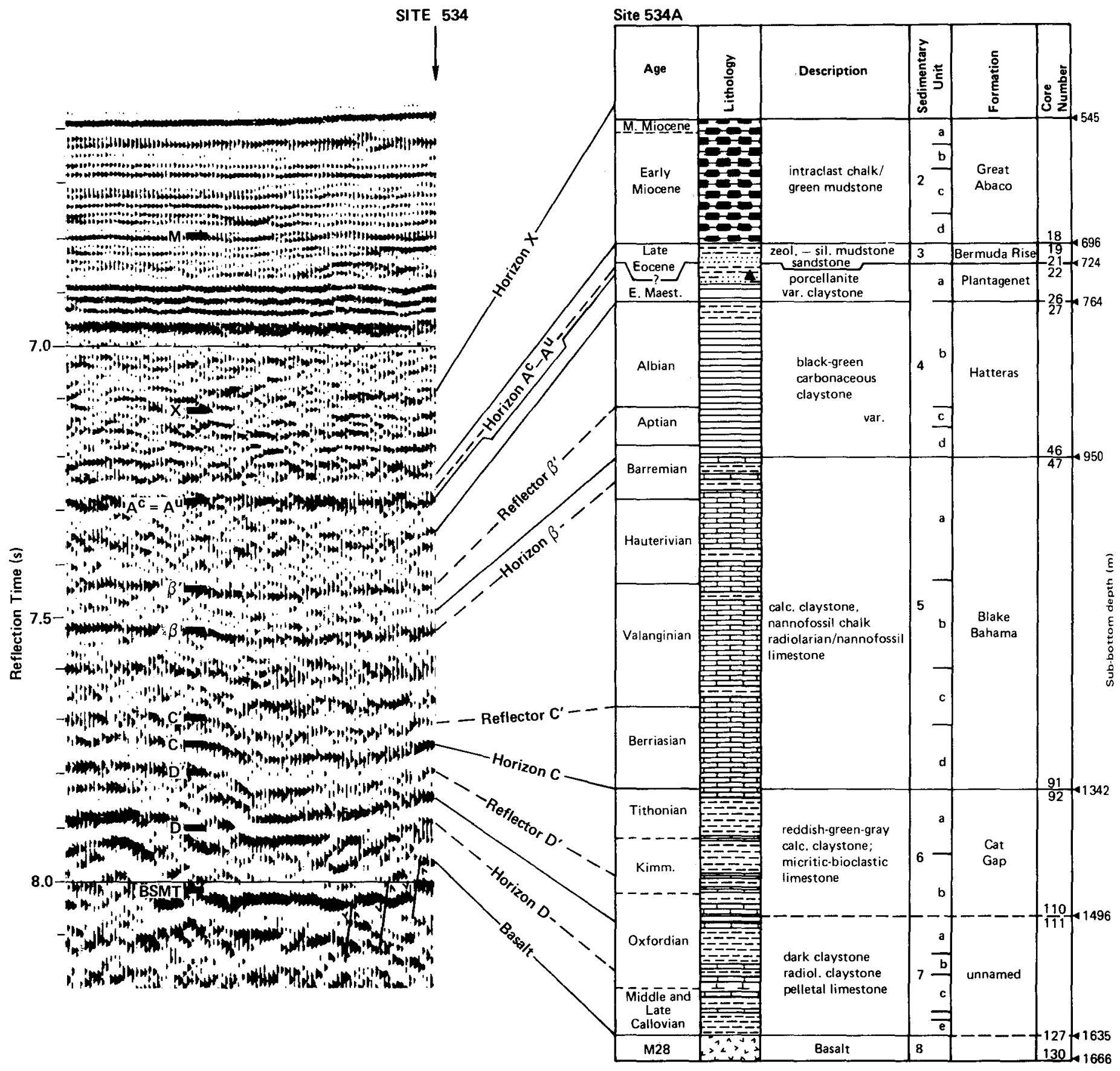

Figure 4. Stratigraphic summary of Hole 534A, Leg 76 of the Deep Sea Drilling Project and tentative correlation to the seismicreflection profile at the site, using shipboard data. The formations are those used in this part of the western North Atlantic Ocean. (Correlation lines are dashed for seismic reflections to indicate uncertainty. Formation-boundary correlations are solid lines). The unnamed unit seven is older than and different from any previously drilled sediment on oceanic basement. The Callovian age for the sediment on basement is 10-30 m.y. younger than previously estimated and leads to a recalibration of the scenario of events during the early opening of the Atlantic Ocean. 
measurements at three different depths. Temperatures as high as $19^{\circ} \mathrm{C}$ were measured at $400 \mathrm{~m}$ depth and indicated a nearly linear temperature gradient of $3.6^{\circ} \mathrm{C} / 100 \mathrm{~m}$ near the bottom of the hole. A slightly higher gradient of $5.1^{\circ} \mathrm{C} / 100 \mathrm{~m}$ was determined for the shallowest part of the hole.

Extrapolation of these temperature measurements to the depth of the BSR, $\sim 690$ $\mathrm{m}$, indicates that the temperatures would be in the range at which methane gas hydrate would decompose. The temperature measurements agree with the interpretation that the BSR is a phase-boundary between gashydrated sediments and normal sediments without gas hydrates.

\section{SITE 534: THE EARLY HISTORY OF THE WESTERN NORTH ATLANTIC OCEAN}

The North American Basin, off the eastern seaboard of the United States, is in proximity to one of the oldest passive continental margins of the modern oceans. The history of this ocean basin is thought to span in excess of $160 \mathrm{~m} . \mathrm{y}$. Drilling during Legs 1, 2, 11, 43, and 44 with D/V Glomar Challenger provided fundamental knowledge of sea-floor spreading, sedimentary and paleoceanographic processes, and history of this basin over the past 145 m.y. (Sheridan and others, 1978; Vogt and Einwich, 1979). The lack of solid information on the earliest history of the North Atlantic Ocean led to the planning of a drill site where yet-undrilled sedimentary strata below seismic reflection Horizon D overlie ocean crust that is more than 150 to 160 m.y. old (Middle Jurassic). Good seismicreflection profiles made during earlier site surveys (Bryan and others, 1980) revealed that basement was within reach of $D / V$ Glomar Challenger's drill string limit $(6,800$ $\mathrm{m})$. Thus, the larger part of Leg 76 was devoted to this objective at Site 534 where basement was found to be as shallow as $1,635 \mathrm{~m}$ below the sea floor in $4,970 \mathrm{~m}$ water depth.

\section{Operations}

We occupied Site 534 from 21 to 22 October, from 29 October until 29 November, and from 5 to 19 December, 1980; a total of 44 days. Two interruptions of work at the site, one for an engine repair and one for a crew change, necessitated port calls at Fort Lauderdale, Florida. Hole preparations at Site 534 included the emplacement of $531 \mathrm{~m}$ of casing string below the re-entry

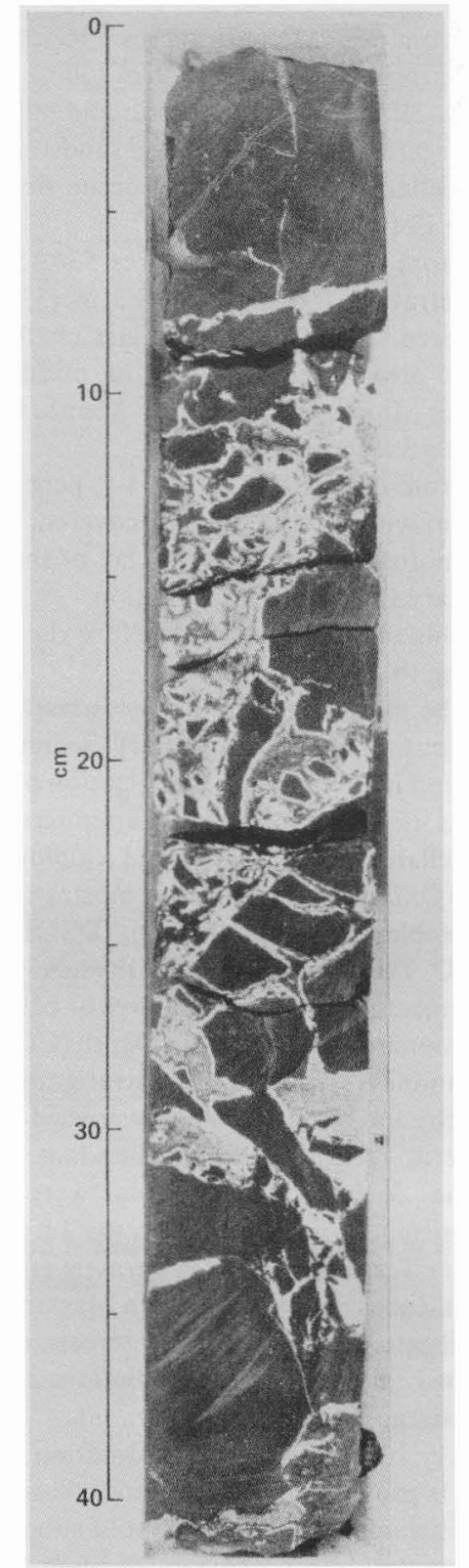

Figure 5. Basalt breccia within massive or pillow basalt. The basalt clasts are overgrown by fibrous calcite cement of probable hydrothermal origin (core 129 of Site 534, Leg 76).

cone in 4,976 m (below rig floor) of water. Hole 534A was drilled to a depth of $1,666.5$ $\mathrm{m}$, using six drill bits. Re-entries varied from easy to very difficult, depending on the apparent presence of variable deep currents. Coring was continuous from $536 \mathrm{~m}$ to $1666.5 \mathrm{~m}$; recovery was $56 \%$ (Table 1). Logging of the hole, which necessitated another two, our seventh and eighth re-entries, was accomplished with measurements of density, sonic velocity, temperature, natural gamma radiation, and hole diameter being made. Leg 76 terminated on 21 December 1980 in Fort Lauderdale.

\section{Lithostratigraphy and Biostratigraphy}

The lithological units penetrated in Site 534 between 0 and 1,496 m sub-bottom are readily assigned to the formations erected for the North American Basin (Jansa and others, 1979) (Fig. 4). The red claystone, dark claystone, olive-gray limestone, and radiolarian silt and claystone between 1,496 $\mathrm{m}$ and $1,635 \mathrm{~m}$ on M-28 oceanic basement, are quite different from and older than the Cat Gap Formation, the oldest known in the Atlantic Ocean. In ascending order, we encountered the following (Fig. 4):

From 1,635-1,666.5 m, in cores 534A, $127-130$, penetrating $31 \mathrm{~m}$ with $17.3 \mathrm{~m}$ $(60 \%)$ recovered, a dark gray aphyric to sparsely microporphyritic basalt (Fig. 5). Green claystone and reddish-brown siliceous limestone with "filaments" fill some of the $1-$ to $5-\mathrm{cm}$ thin fractures in the basalt and are present as thin (less than $7 \mathrm{~cm}$ ) interbeds.

From 1,496-1,635 m, in cores 534A, 112127 , penetrating $139 \mathrm{~m}$ with $39.8 \mathrm{~m}(29 \%)$ recovered, a dark variegated claystone underlain by olive-gray pelletal limestone and radiolarian claystone, underlain by greenish-black to brown nannofossil claystone terminating in reddish, almost massive claystone (Fig. 6).

This is a new unnamed lithostratigraphic unit of middle Callovian through early middle Oxfordian age. There is similarity in lithology to the Bathonian-middle Oxfordian "Terres Noires," a sequence of pelagic, dark calcareous, silty claystone with interbeds of calcareous turbidites, deposited along the northern margin of Tethys in southeastern France.

From $1,342-1,496 \mathrm{~m}$, in cores $534 \mathrm{~A}$, 92-111, penetrating $154 \mathrm{~m}$ with $74.6 \mathrm{~m}$ $(48 \%)$ recovered, a grayish-red, calcareous claystone underlain by dark greenish-gray claystone with interbedded limestone of the Tithonian through Oxfordian Cat Gap Formation.

From 950-1,342 m, in cores 534A, 47-91, penetrating $392 \mathrm{~m}$ with $298.4 \mathrm{~m}(76 \%)$ recovered, a bioturbated and laminated radiolarian-rich nannofossil limestone and chalk, grading upward into calcareous claystone and carbonaceous claystone, redistributed shelf limestones and quartzose siltstones, of the Barremian through lower Berriasian Blake Bahama Formation.

From 764-950 m, in cores 534A, 27-46, penetrating $186 \mathrm{~m}$ with $83.2 \mathrm{~m}(45 \%)$ recov- 


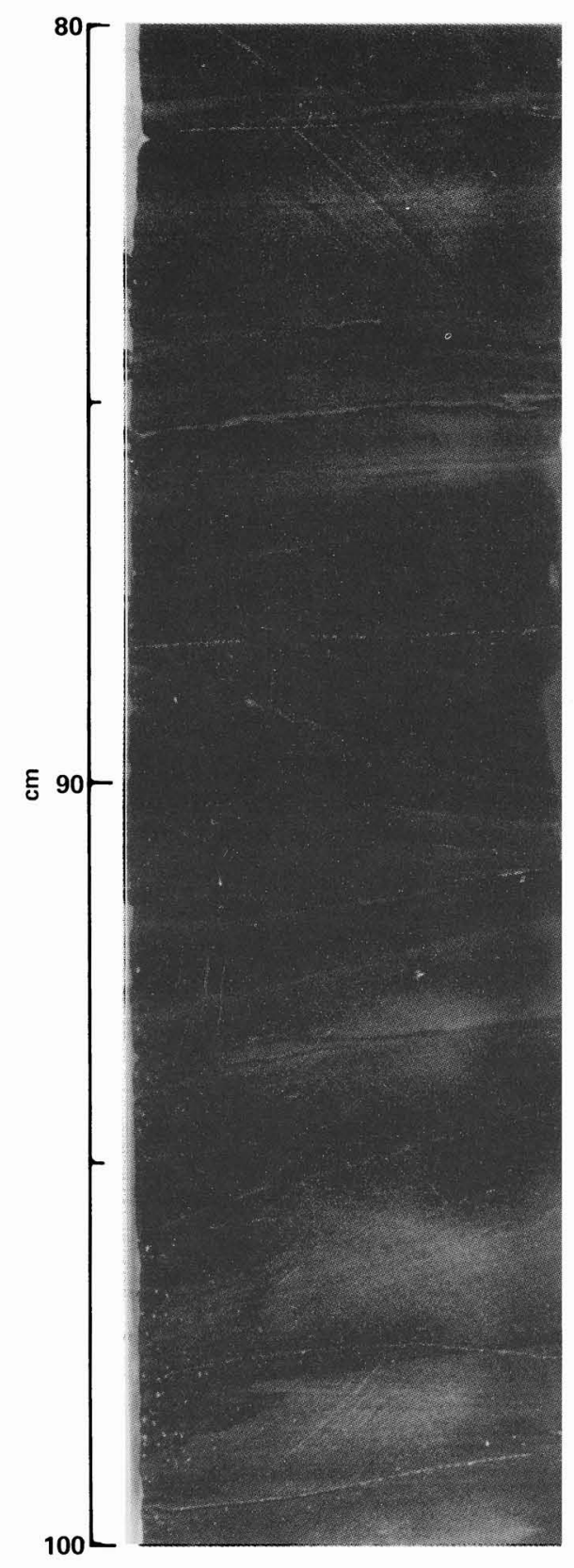

Figure 6. A portion of core 125, Site 534 in the western North Atlantic Ocean composed of dark, laminated claystone with low-angle cross-bedding. This sediment was deposited in Callovian time almost immediately above oceanic basement and is older than any other sediment drilled in the oceans (core 125-4-80-100 cm of Site 534).

ered, a black to green carbonaceous claystone of the Cenomanian through lower Aptian Hatteras Formation.

From 724-764 m, in cores 534A, 22-26, penetrating $40 \mathrm{~m}$ with $9.9 \mathrm{~m}(25 \%)$ recovered, a variegated claystone of the lower Maestrichtian Plantagenet Formation.
SHERIDAN, GRADSTEIN, AND OTHERS

From 696-724 m, in cores 534A, 19-21, penetrating $28 \mathrm{~m}$ with $8.3 \mathrm{~m}(30 \%)$ recovered, an interbedded zeolitic and siliceous, variegated mudstone, graded sandstone and porcellanite of the upper Eocene Bermuda Rise Formation.

From $536-696 \mathrm{~m}$, in cores $534 \mathrm{~A}, 1-18$, penetrating $160 \mathrm{~m}$ with $83.5 \mathrm{~m}(53 \%)$ recovered, chalks and intraclast chalks and dark green mudstones of the middle and lower Miocene Great Abaco Member of the Blake Ridge Formation.

From $0-2.8 \mathrm{~m}$, in core $534-1$, penetrating $2.8 \mathrm{~m}$ with $2.8 \mathrm{~m}(100 \%)$ recovered, a gray nannofossil ooze and silty clay of the Quaternary Blake Ridge Formation.

This unit was sampled before the casing string to $531 \mathrm{~m}$ was placed.

The biostratigraphy of the Jurassic, Cretaceous, and lower Tertiary sedimentary section is based on the interrelation of zonations using nannofossils, foraminifers, dinoflagellates, radiolarians, and calpionellids. The Oxfordian and younger biostratigraphy resembles that described for DSDP Hole 391C. The abyssal nature of the hemipelagic sediments deposited just above or below the Carbonate Compensation Depth (CCD) for foraminifers resulted in a stratigraphically patchy and often much impoverished foraminiferal record, without abundant planktonic forms. Nannofossils were most consistently present through the Jurassic to lower Tertiary, except in Jurassic and midCretaceous dark shales and in Maestrichtian variegated shales. In those intervals, organic walled microfossils and radiolaria assist in stratigraphic assignments.

Key biostratigraphic information in Site 534 is provided by (1) the nannofossil zonation which allows a twelve-fold subdivision in the middle Callovian through Albian strata; (2) a middle Callovian age in the lowermost cores based on nannofossil, radiolarian, and palynomorph biostratigraphy; (3) the L. quenstedti, E. aff. uhligi foraminifer assemblages characteristic of the E. mosquensis Zone in and below core 99, which is not younger than early Tithonian in age; (4) the identification of Calpionella B Zone in cores 92 (top)-90 indicative of latest Tithonian-earliest Berriasian beds and of Zone A in cores 93-92 (bottom), definitely Tithonian; (5) Aptian-Albian dinoflagellate stratigraphy in the Hatteras shales, and (6) a presumably in situ Globotruncana foraminifera assemblage in cores 23-26 of early Maestrichtian age, and the late Eocene nannoflora assigned to the $D$. barbadiensis to $G$. saipanensis Zones in cores 19 to 21 .
The Miocene stratigraphy in Site 534, as in Hole 391C, uses a combination of standard nannofossil and planktonic foraminiferal zonations; resolution is better than that in the older beds.

\section{Seismic Stratigraphy}

Laboratory velocity measurements and in situ impedance calculations compare favorably with the correlation of seismic reflectors to drill-hole lithologies and hiatuses. Tentative seismic stratigraphic correlations (Fig. 4) were made with certain depths in the well. These reflections are thought to derive from bedding impedance contrasts for Horizons $A^{c}$ (upper Eocene porcellanitic claystone), $\beta$ (Barremian limestone), $C$ (upper Tithonian red shaly limestone), and D (lower Oxfordian turbiditic limestone). Other reflections are attributed to impedance contrasts associated with possible unconformities, such as Horizon $\mathrm{A}^{\mathrm{u}}$ (lower Miocene-upper Eocene), $\beta^{\prime}$ (lower Albianupper Aptian), $C^{\prime}$ (upper Berriasian-lower Berriasian), and $D^{\prime}$ (Kimmeridgian-Kimmeridgian). At present, these are the best estimates for ages of the seismic horizons. Synthetic seismogram modeling is underway to test these correlations.

The ages of Horizons $\mathrm{A}^{\mathrm{u}}, \beta$, and $\mathrm{C}$ at Site 534 agree with previously published correlations. The age of Horizon D, drilled for the first time at Site 534, is younger than the early Callovian age (Bryan and others, 1980) and older than the Tithonian age (Vail and others, 1980) predicted in the literature.

\section{Age of Basement}

The magnetostratigraphy of the sedimentary column in Site 534A could not be ascertained onboard, but the directions of magnetization of the basaltic basement rocks are consistent with the Jurassic paleolatitude of the site. The middle Callovian age assignment of the basal beds is verified by nannofossil, palynomorph, and radiolarian stratigraphy. In order to reach basement within the engineering drill string limit, Site 534 was positioned on the north flank of a fracture zone trough. As a result, basement was penetrated at a shallower depth than the sediments in the adjacent trough. However, because the seismic profiles suggested that the hemipelagic sediment cover on the basement at Site 534 formed more or less simultaneously in troughs and on highs, we are confident that the biostratigraphy of the 
basal sediments provides a reliable estimate of the minimum age for the basement at Site 534.

\section{Depositional History}

The thick Jurassic, Cretaceous, and Tertiary-Quaternary stratigraphic sequence is the result of relatively continuous slow sedimentation interrupted periodically by fast sedimentation. There was a slow, 0.1 $\mathrm{cm} / 10^{3} \mathrm{yr}$ or less, but more or less continuous hemipelagic "background" sedimentation on a sea floor between the CCD for foraminifers and nannofossils. On this record is superimposed periodic sedimentation by turbidity currents, debris flows or bottom currents of slope or shelf carbonate and carbonaceous claystone at average rates as high as $4 \mathrm{~cm} / 10^{3} \mathrm{yr}$ (Fig. 7). Threequarters of this sediment (decompacted thickness) was deposited during the first $\mathbf{5 0}$ m.y. after the site formed at the mid-ocean ridge $\sim 154 \mathrm{~m} . \mathrm{y}$. ago. The overlying section, largely of Miocene and younger age, accumulated in the past $20 \mathrm{~m} . \mathrm{y}$. The main periods of redeposited carbonates are in the early part of the Early Cretaceous and in the Miocene; carbonaceous claystones are the dominant deposits in the basin in midCretaceous time. Redeposited quartz sand and silt form a minor constituent of the cored section, which can be explained by the damming effect of the carbonate barrier platform to the west and southwest of the basin and by the very distal location of the site.

The basal sediments and several interbeds in the basalts are red, weakly laminated to massive claystone which contain some flattened burrows. There is no obvious basal ferromanganese horizon at Site 534. The color and sedimentary features point to oxidizing bottom waters without strong current activity in the basal Callovian deposits.

The Middle and Upper Jurassic brown and green-black, radiolarian-rich claystone and redeposited limestones indicate hemipelagic sedimentation, modified by slope and shelf-derived turbidites and bottom-current transport. The various green, red, gray, and black colors largely reflect organic matter and sulfide content surviving after diagenesis. Sedimentary structures indicate deposition of the black shale laminae largely by dilute turbidity currents. One alternative is that the black shales reflect periodical organic-matter input (mostly terrestrial), possibly related to fluctuating climate on land. In this case, bottom waters need not

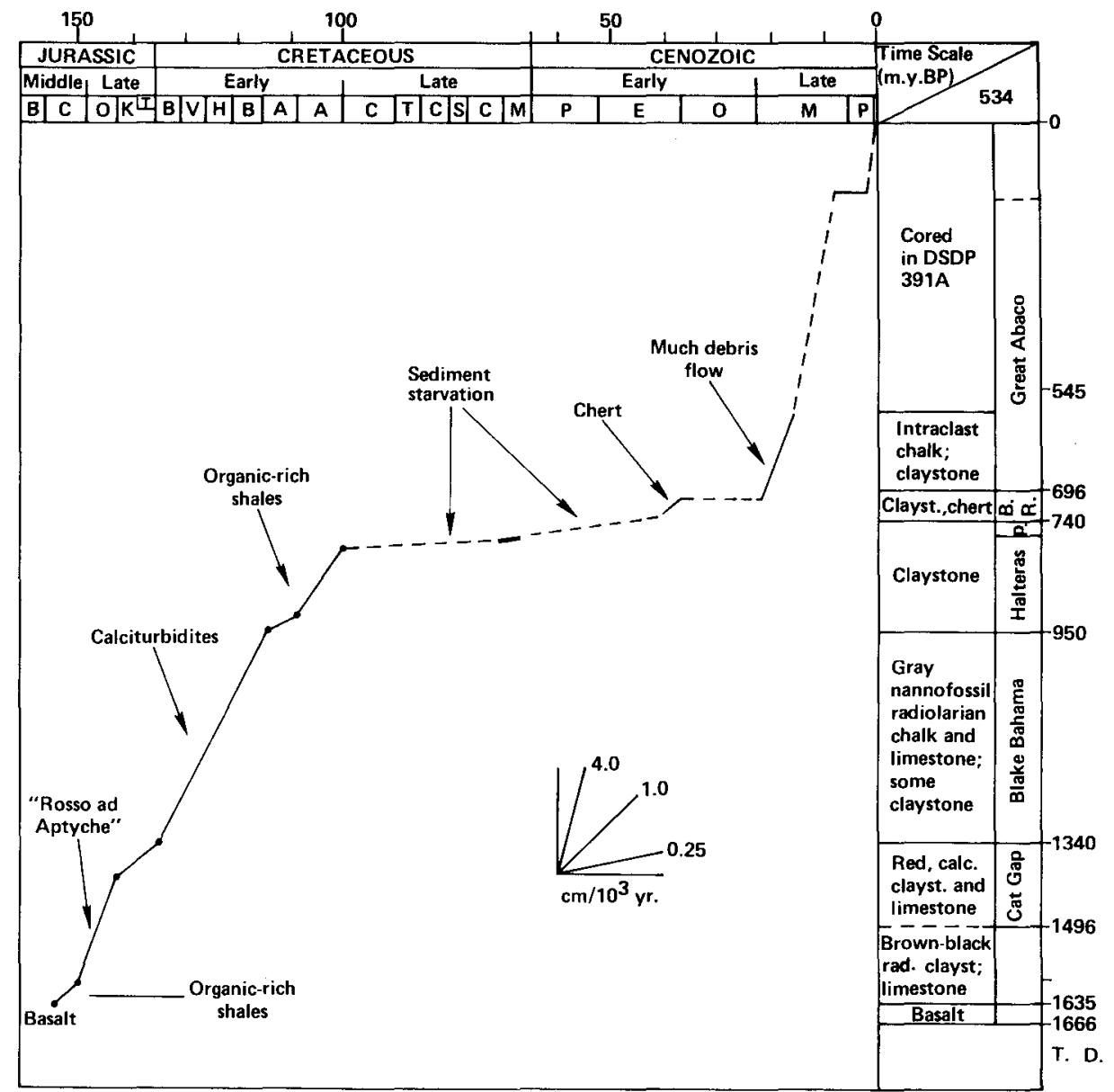

Figure 7. Sediment accumulation at Site 534, Leg 76, Blake-Bahama Basin. For explanation see text.

be anoxic. Alternatively, pools of reduced bottom water may have existed for short periods on the Callovian sea floor.

Sedimentary structures, especially lowangle cross-bedding and winnowing effects (Fig. 6), show that the Middle-Late Jurassic Atlantic Ocean basin may have had some bottom circulation, leading to possible contourite deposition. The Jurassic ocean surface water sustained rich radiolarian faunas and nannofloras, indicative of an ocean with well-established surface circulation. These observations suggest a continuous open marine connection to the European Tethys and probably the Pacific as well. This connection is also shown by the presence of primitive planktonic foraminifers of Oxfordian age. These are some of the oldest known and correlate with an abundance peak in the Mediterranean basin margins.

The major influx of pelagic and redeposited carbonates in Berriasian to Barremian (Early Cretaceous) time gradually changed to predominantly carbonaceous claystone accumulation during Aptian-Cenomanian time. The CCD shoaled sharply in Barremian through Aptian time and resulted in carbonate-depleted sediment. Much of the thin (15-cm-thick) carbonaceous claystone was deposited by distal turbidity currents. Ubiquitous very fine laminations may be the result of extremely distal turbiditic or nepheloid deposition. The organic matter is mostly terrigenous and less marine in origin, possibly reflecting a wet climate on land and an oxidizing environment on the sea bottom. Alternatively, the bottom water may have become anoxic for at least some time. Based on the level of thermal maturation, kerogen type, and organic content, the carbonaceous claystone may be considered a potential source rock of gas. There are distinct alternations (cycles) of primary and pedogenic (compare illite to smectite) clay minerals and distinct peaks in organic abundance; organic matter peaks correlate to similar peaks at other sites in the Atlantic Ocean. The variegated upper Aptian sequences contain minor silt layers and moreresistant clay minerals, which indicate a 
marked change in environment with improved bottom circulation, slower accumulation, or winnowing.

A surprising find was several tens of metres of thin, variegated claystone and interbedded zeolitic-siliceous mudstone, siltstone, and minor porcellanite of late Eocene age (Fig. 4) where the Miocene-Cenomanian disconformity (of nearby Site 391) drilled during Leg 44 was expected. The previous postulation of as much as $800 \mathrm{~m}$ of (mostly Oligocene) erosion, based on somewhat tenuous coalification data in the Aptian-Albian and Miocene strata (Dow, 1978), may need revision. Rather, we conclude that there was extensive sediment starvation in the Late Cretaceous and Paleogene Blake-Bahama Basin that led to low net sediment accumulation without large-scale sediment erosion.

In the lower Miocene, one continuously graded unit over $10 \mathrm{~m}$ thick was observed that could relate to the same depositional event as observed at Site $391,22 \mathrm{~km}$ southwestward. Similar and coeval deposits have been found during DSDP cruises off Morocco, which suggests a common cause(s) for their formation. We are not certain if oversteepening of the shelf terrace due to the Oligocene eustatic sea-level lowering, or Alpine tectonics (in the Atlas Mountains and Cuba-Antilles) (or both), was the cause of large-scale Miocene gravity redeposition.

\section{Sea-Floor Spreading}

The North Atlantic Ocean is generally thought to have rifted in Triassic to Early Jurassic time, with significant opening beginning not later than late Early Jurassic time. This date of opening is largely derived from estimates for early spreading of $\sim 2$ $\mathrm{cm} / \mathrm{yr}$ (Vogt and Einwich, 1979). Now, however, our finding of Callovian sediments on M-28 anomaly basement indicates an early spreading rate almost twice as fast (Fig. 4).

Extrapolation of the new $3.8 \mathrm{~cm} / \mathrm{yr}$ spreading rate leads us to date the Blake Spur magnetic anomaly as basal Callovian ( $\sim 155$ m.y. on the van Hinte, 1976, time scale), which is about 20 m.y. younger than at one time thought (Vogt and Einwich, 1979). The young age means that the shift of the major spreading center along the Blake Spur anomaly that marked the beginning of the "true" modern North Atlantic also

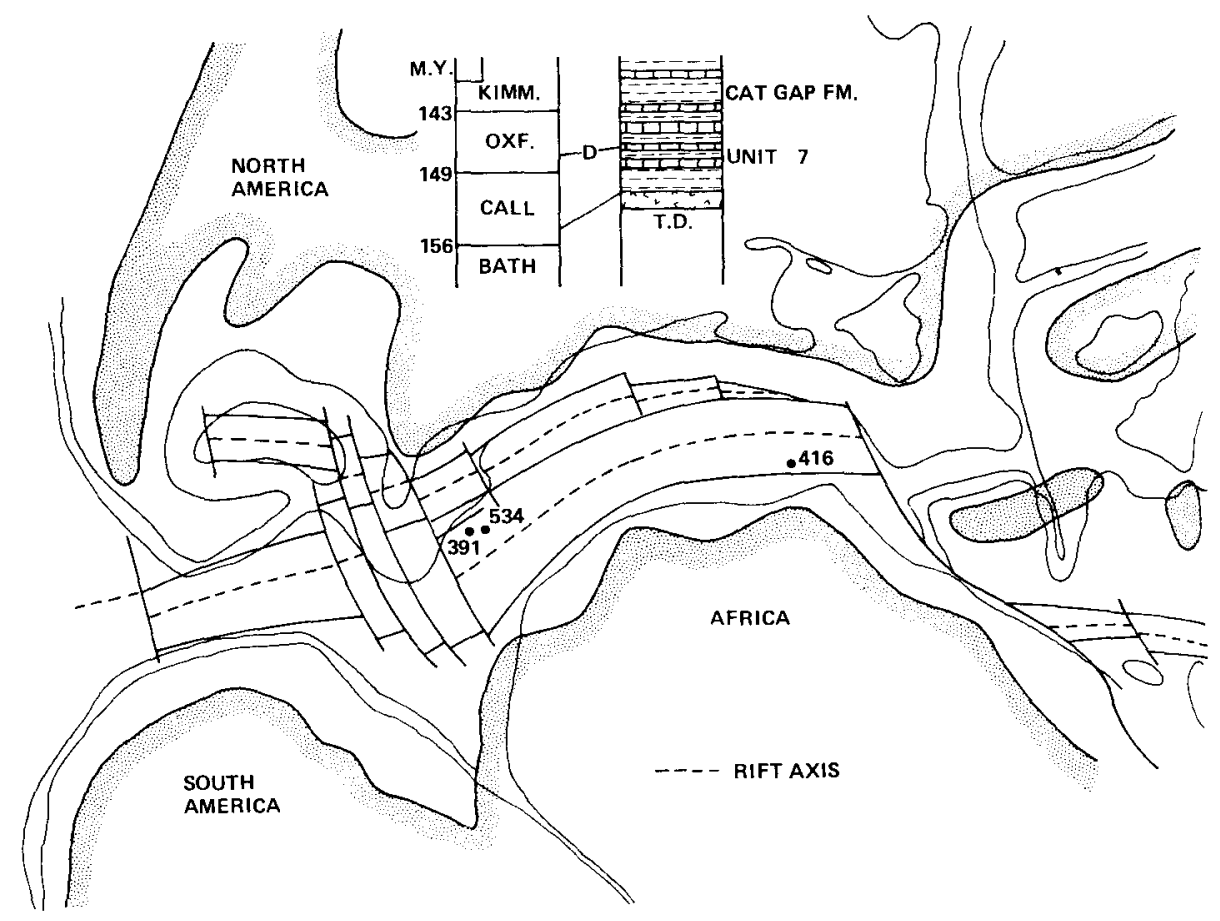

Figure 8. Tentative reconstruction of North Atlantic paleogeography, at M-26 magnetic anomaly time or approximately middie Oxfordian (145 m.y. ago), shortly after Site 534 appeared on the central spreading ridge. The extinct proto-Atlantic rift of Blake Spur magnetic anomaly time, $\sim 155 \mathrm{~m}$.y. old, has been isolated on the North American plate, and Jurassic ocean crust formed from the Caribbean to the Grand Banks.

occurred much later in time than often thought.

Stratigraphically, the Callovian deposits around the North Atlantic mark the onset of a rapid, widespread transgression (Hallam, 1975). By Late Jurassic, this transgression spread to the deep interior of the continents, indicating a global rise in sea level (Hallam, 1975). Generally, the breakup of continental crust to form ocean crust is punctuated by a pulse of rapid subsidence and rapid transgression over the breakup unconformity on the continental margins. This widespread circum-Atlantic Callovian transgression thus would be a record of the Blake Spur spreading-center jump. The continuation of the eustatic rise in sea level into the Late Jurassic was probably caused by the newly formed, fast-spreading North Atlantic Ridge (Fig. 8).

Drilling at Site 534 recovered the first evidence of fast spreading associated with the Jurassic magnetic quiet zone. This relation is similar to that for the Cretaceous quiet zone, suggesting a link between the processes causing rapid plate motions in the upper mantle and the processes controlling the magnetic field at the core-mantle boundary. Plume eruptions from the lowermost mantle might connect the two processes and explain the pulses of fast spreading as well as the decrease in reversals of the magnetic field.

\section{ACKNOWLEDGMENTS}

Much credit goes to the planning panels of JOIDES and to the technical staff of the Deep Sea Drilling Project, which are administered by the U.S. National Science Foundation, and to the marine and drilling crew of the D/V Glomar Challenger, for high performance in achieving the scientific objectives of Leg 76 .

\section{REFERENCES CITED}

Bernard, B. B., Brooks, J. M., and Sackett, W. L., 1978, Light hydrocarbons in recent Texas continental shelf and slope sediments: Journal of Geophysical Research, v. 87, p. 4053-4061.

Bouma, A. H., and Hollister, C. D., 1973, Deep 
ocean basin sedimentation, in Middleton, $\mathrm{G}$. M., and Bouma, A. H., eds., Turbidites and deep-water sedimentation: Society of Economic Paleontologists and Mineralogists Short Course, p. 79-118.

Bryan, G. M., Markl, R. G., and Sheridan, R. E., 1980, IPOD site surveys in the Blake Bahama Basin: Marine Geology, v. 35, p. 43-63.

Claypool, G. E., Presley, B. J., and Kaplan, I. R., 1973, Gas analysis of sediment samples from Legs $10,11,13,14,15,18$, and 19, in Creager, J. S., Scholl, D. W., and others, Initial reports of the Deep Sea Drilling Project, Volume 19: Washington, D.C., U.S. Government Printing Office, p. 879-884.

Dillon, W. P., Grow, J. A., and Paull, C. K., 1980, Unconventional gas hydrate seals may trap gas off southeast U.S.: Oil and Gas Journal, v. 87, no. 1, p. 124-130.

Dow, W. G., 1978, Geochemical analyses of samples from Holes 391A and 391C, Leg 44. Blake-Bahama Basin, in Benson, W. E., Sheridan, R. E., and others, Scientific Editors, Initial reports of the Deep Sea Drilling Project, Volume 44: Washington, D.C., U.S. Government Printing Office, p. 625-634.

Hallam, A., 1975, Jurassic environments: London, Cambridge University Press, 269 p.

Hand, J. H., Katz, D. L., and Verina, V. K., 1974, Review of gas hydrates with implication for ocean sediments, in Kaplan, I. R., ed., Natural gases in marine sediments: New York, Plenum Press, p. 179-194.

Heezen, B. C., Hollister, C. D., and Ruddiman, W. F., 1966, Shaping of the continental rise by deep geostrophic contour currents: Science, $v .152$, p. 502-508.

Hesse, R., and Harrison, W. E., 1980, Abnor- mally low pore-water salinities in deep marine sections of the continental margins related to gas hydrate (clathrate) occurrence: Geological Society of America Abstracts with Programs, v. 12, p. 446.

Hollister, C. D., Ewing, J. I., and others, 1972, Sites 102-103-104 Blake-Bahama Outer Ridge (northern end), in Hollister, C. D., Ewing, J. I., and others, Scientific Editors, Initial reports of Deep Sea Drilling Project, Volume 11: Washington, D.C., U.S. Government Printing Office, p. 135-218.

Jansa, L. F., Enos, P., Tucholke, B. E., Gradstein, F. M., and Sheridan, R. E., 1979, Mesozoic-Cenozoic sedimentary formations of the North American basin; western North Atlantic, in Talwani, M., Hay, W., and Ryan, W.B.F., eds., Deep drilling results in the Atlantic Ocean: Continental Margins and Paleoenvironments: American Geophysical Union, Ewing Conference Series, v. 3, p. $1-57$.

Markl, R. G., Bryan, G. M., and Ewing, J. I., 1970, Structure of the Blake-Bahama Outer Ridge: Journal of Geophysical Research, v. 75 , p. $4539-4555$.

Paull, C. K., and Dillon, W. P., 1979, The appearance and distribution of the gas hydrate reflector off the southeastern United States: U.S. Geological Survey Open-File Report, $23 \mathrm{p}$.

Sayles, F. L., Manheim, F. T., and Waterman, L. S., 1972, Interstitial water studies on small core samples, Leg 11, in Hollister, C. D., Ewing, J. I., and others, 1972, Initial reports of Deep Sea Drilling Project, Volume 11: Washington, D.C., U.S. Government Printing Office, p. 997-1008.

Sheridan, R. E., Enos, P., Gradstein, F. M., and
Benson, W. E., 1978, Mesozoic and Cenozoic sedimentary environments of the western North Atlantic, in Benson, W. E., Sheridan, R. E., and others, Scientific Editors, Initial reports of the Deep Sea Drilling Project, Volume 44: Washington, D.C., U.S. Government Printing Office, p. 529-546.

Vail, P. R., Mitchum, R. M., Jr., Shipley, T. H., and Buffler, R. T., 1980, Unconformities of the North Atlantic: Royal Society of London Philosophical Transactions, v. A 294, p. $137-155$

van Hinte, J. E., 1976, A Jurassic time scale: American Association of Petroleum Geologists Bulletin, v. 60 , p. $489-497$.

Vogt, P. R., and Einwich, A. M., 1979, Magnetic anomalies and sea-floor spreading in the western North Atlantic, and a revised calibration of the Keathley (M) geomagnetic reversal chronology, in Tucholke, B. E., Vogt, P. R., and others, Scientific Editors, Initial reports of Deep Sea Drilling Project, Volume 43: Washington, D.C., U.S. Government Printing Office, p. 971-974.

Whelan, J. K., and Sato, S., 1980, $C_{1}-C_{5}$ hydrocarbons from core gas pockets, Deep Sea Drilling Project Legs 56 and 57, Japan Trench transect, in Scientific Party, Initial reports of Deep Sea Drilling Project, Volumes 56, 57: Washington, D.C., U.S. Government Printing Office, p. 1335-1347.

Manuscript Received by the Society September 16, 1981

Manuscript ACCepted Septemrfr 28, 1981 